\title{
How apple responds to boron excess in acidic and limed soil
}

\author{
A. Paparnakis ${ }^{1}$, C. Chatzissavvidis ${ }^{1 *}$, V. Antoniadis $^{2}$ \\ ${ }^{1}$ Department of Agricultural Development, Democritus University of Thrace, Orestiada 68200, Greece. ${ }^{2}$ Department of \\ Agriculture, Crop Production and Rural Environment, University of Thessaly, Volos 38446, Greece. ${ }^{*}$ Corresponding author: \\ cchatz@agro.duth.gr
}

\begin{abstract}
Two year-old apple plants (Malus domestica cv. Red Chief Delicious) were grown in an acidic and limed soil, and fertilized with B (0, 1, 3 and $5 \mathrm{mg} \mathrm{kg}^{-1}$ soil). Fresh matter weight of plants was positively correlated with the applied $\mathrm{B}$ only in acidic soil. The number of nods, plant height, stem diameter, and shoot length were not particularly affected by either B additions or liming. The length of internodes of the plants grown in limed soil showed a positive correlation with the amount of added $\mathrm{B}$, but the opposite effects were observed in the acidic soil. Boron and $\mathrm{K}$ concentration in leaves showed a positive correlation with added $\mathrm{B}$ in both soils. Leaf $\mathrm{N}$ and Fe concentrations were negatively affected by $\mathrm{B}$ additions in soils, while leaf $\mathrm{Mn}$ and $\mathrm{Zn}$ concentrations were also affected by added $\mathrm{B}$ and soil $\mathrm{pH}$, reflecting thus their soil mobility. Chlorophyll content in leaves was reduced at high $\mathrm{B}$ treatments, only in plants grown in the acidic soil. Our results show that added B even in our high B-content acidic soil did not cause any detrimental effects on apple plants, and that liming seemed to buffer trace metal excesses, characteristic of any acidic soil.
\end{abstract}

Keywords: Chlorophyll, liming, Malus domestica, soil pH, toxicity

\section{Introduction}

Boron is a micronutrient which is necessary for the normal growth of plants. It is unique among the other micronutrients in that the threshold between deficiency and toxicity is narrow (Shuang et al., 2009). Its role in plant, particularly in cell wall pectin and cell wall physical characteristics, has long been identified. For example, pectin polysaccharide rhamnogalacturan II, the first B-containing compound identified in plant kingdom, has been reported as an agent providing stability to the cell wall matrix (Goldbach and Wimmer, 2007).
Apple is among the most B-sensitive plants, commonly affected by either deficiency or excess of B (Jones, 1998). Typical B toxicity symptoms may include decreased leaf chlorophyll (Chl), altered metabolism and necrosis of mature tissues, while B deficiency symptoms may be similarly severe (Reid et al., 2004). Boron is available to plants as boric acid $\left(\mathrm{H}_{3} \mathrm{BO}_{3}\right)$, which is ionized to boric anion at alkaline soil $\mathrm{pH}$ values. Due to the non-cationic nature of $\mathrm{B}$, rain tends to leach $\mathrm{B}$ relatively easily down the soil profile, and deplete it from the root zone, especially in low soil $\mathrm{pH}$ values. 
Given the fact that the majority of investigations on $\mathrm{B}$ are being conducted in temperate or high-rainfall areas, research efforts have mainly concentrated on problems related with B deficiency. However, in countries affected by the Mediterranean climate, where high rainfall is not usual, B is not commonly leached from soils. On the other hand, B adsorption by soil colloids has been found to increase with soil $\mathrm{pH}$ (Goldberg, 1993), and this implies that B may either be more prone to leaching or more easily taken up by plants in acidic soils. However, in dry Mediterranean regions, less adsorption in acidic soils does not necessarily mean depletion due to leaching, as would rather be expected in high-rainfall climates, and thus even in such soils plants may suffer from B excess. Boron availability and uptake behavior also remains unknown in limed previously acidic soils, because other nutrients are expected to alter their mobility, creating unpredictable antagonisms or synergisms as $\mathrm{pH}$ increases, and this may in turn affect $\mathrm{B}$ as well. Thus the role of liming in B dynamics under semi-arid conditions in apple plants is not clear and needs to be addressed and evaluated.

The aim of this study was to test B uptake and availability, as well as some major agronomic characteristics of apple plants in acid and limed soil.

\section{Materials and Methods}

\subsection{Experimental design}

This outdoor pot experiment was carried out during the period 9 May 2009 - 13 September 2009, at the Department of Agricultural Development, Democritus University of Thrace (long $26^{\circ} 32^{\prime} \mathrm{E}$, lat $41^{\circ} 30^{\prime} \mathrm{N}$; altitude $41 \mathrm{~m}$; Orestiada, Greece). Two year-old, uniform apple (Malus domestica Borkh cv. Red Chief Delicious) plants budded on MM106 rootstock were planted in 5-L plastic pots containing soil mixed with perlite at a ratio of 1:1 for better aeration. Half of the plants were planted in a native acidic soil mixture (with
$\mathrm{pH} 4$ ) and the other half in pots where soil had been limed with an equivalent of $0.60 \mathrm{~g} \mathrm{CaO}$ per liter soil to a target $\mathrm{pH}$ value of 6.5 . The soil was a silt loam (clay $84 \mathrm{~g} \mathrm{~kg}^{-1}$, sand $411 \mathrm{~g} \mathrm{~kg}^{-1}$, silt $505 \mathrm{~g} \mathrm{~kg}^{-1}$ ), with organic C $12.1 \mathrm{~g} \mathrm{~kg}^{-1}$ and electrical conductivity $\left(1: 5 \mathrm{H}_{2} \mathrm{O}\right)$ of $0.60 \mathrm{mS} \mathrm{cm} \mathrm{cm}^{-1}$. Each soil was divided into four parts and received $0,1,3$ and $5 \mathrm{mg} \mathrm{B} \mathrm{kg}^{-1}$ soil as boric acid. Each treatment consisted of five plants (replications). The plants were irrigated every two days with $500 \mathrm{~mL}$ of tap water per pot. From the pots no drainage was allowed. Any amount of leached water from the pots was collected in individual pot dishes and was allowed to be absorbed back into the pots. The treatment with no added $\mathrm{B}$ was considered as control. The daily mean temperature during the experiment ranged between 20.1 and $26.9{ }^{\circ} \mathrm{C}$ and the pots received an additional $254 \mathrm{~mm}$ of rain.

\subsection{Sample preparation}

Leaf, rootstock and root samples obtained at the end of the experiment were washed twice with deionized water. The plant parts were then cut into small pieces and dried at $75{ }^{\circ} \mathrm{C}$ for approximately $48 \mathrm{~h}$. Once dry, the individual plant parts were ground into fine powder (30-mesh screen) and stored in the dark at room temperature (approximately $23{ }^{\circ} \mathrm{C}$ ) until analysis.

\subsection{Elemental analysis}

Tissue B extraction was carried out by dry ashing of 0.5 $\mathrm{g}$ dried sample in a muffle furnace at $500{ }^{\circ} \mathrm{C}$ for $6 \mathrm{~h}$. The ash was dissolved in $10 \mathrm{~mL}$ of $0.1 \mathrm{M}$ hydrochloric acid $(\mathrm{HCl})$ and $\mathrm{B}$ was determined colorimetrically at 420 $\mathrm{nm}$ by the Azomethine-H method (Bingham, 1982). The analytical determination of $\mathrm{N}$ was performed using the Kjeldahl method (Jones, 1991a). Potassium was analyzed with flame photometer and microelements $\mathrm{Zn}, \mathrm{Mn}$, and Fe were determined by atomic absorption spectrophotometer from the same plant extracts as that used for B, using standard methods (Jones, 1991b).

The Chl concentration was determined in fully developed leaves $\left(4^{\text {th }}\right.$ to $5^{\text {th }}$ leaf from the apex of the 
plant), estimated by extraction of leaf disks (diameter of $0.9 \mathrm{~cm}$ ) with $96 \mathrm{~g} \mathrm{~L}^{-1}$ ethanol in a water bath at $78{ }^{\circ} \mathrm{C}$, until complete discoloration of the disks. The absorbance of the extracts was measured at 665 and $649 \mathrm{~nm}$. Total Chl $(a+b)$ content was calculated with the equations given by Wintermans and De Mots (1965) and expressed on a dry matter basis.

\subsection{Data analysis}

The experimental layout included two types of soil, four B concentrations and five replicates (plants) per treatment. Data were subjected to analysis of variance (ANOVA). For comparison of means the Duncan's multiple range test was used at the 0.05 probability level using the SPSS v. 19 statistical package (SPSS Inc., Chicago, IL, USA).

\section{Results}

\subsection{Plant growth}

The plants treated with 3 and $5 \mathrm{mg} \mathrm{B} \mathrm{kg}^{-1}$ showed the typical chlorosis of $\mathrm{B}$ excess in leaves and these symptoms were more severe in the acidic soil. The first sign of B toxicity symptoms was chlorotic tissues at the tips and margins of the older leaves that gradually were developed to brown, necrotic areas. In the limed soil, chlorosis in the treatments of 3 and $5 \mathrm{mg} \mathrm{B} \mathrm{kg}^{-1}$ covered about $10 \%$ and $25 \%$ of the total leaf area, respectively, while in the acidic soil the respective values were about $25 \%$ and $50 \%$.

The longest internodes were recorded in the control plants grown in limed soil (Table 1). Most B treatments decreased the length of internodes but not always significantly. The total length of new shoots ranged between 21.4 and $48.2 \mathrm{~cm}$ and it was not affected by soil $\mathrm{pH}$. The addition of $\mathrm{B}$ increased the total shoot length only at 3 and $5 \mathrm{mg} \mathrm{B} \mathrm{kg}^{-1}$ in the limed soil compared to the control, but this increase was slight and non significant. In the acidic soil there was a decrease in shoot length as B additions increased, but the effect was not significant either. Moreover, plant height ranged between 40 and $77 \mathrm{~cm}$, and it was not affected by $\mathrm{B}$ additions, apart from a decrease at $1 \mathrm{mg} \mathrm{kg}^{-1}$ in the limed soil. As for the plant main stem diameter, it increased in both soils with added $\mathrm{B}$, although not significantly, except for the $3 \mathrm{mg} \mathrm{kg}^{-1}$ treatment in the acidic soil, where diameter increase was significant compared to the control. Finally, the fresh matter weight of plants grown in the acidic soil was significantly increased with added B at 3 and $5 \mathrm{mg}$ $\mathrm{kg}^{-1}$ compared to the control. The two variables (fresh weight and added B) were also positively correlated $\left(\mathrm{r}^{2}=0.845\right.$, significant at $\left.p<0.05\right)$. Added B had no statistically significant effect on fresh weight in the limed soil. At $3 \mathrm{mg} \mathrm{kg}^{-1}$ in the acidic soil fresh weight was significantly higher than that in the limed soil. The same trend was observed at $5 \mathrm{mg} \mathrm{kg}^{-1}$ as well, but the difference was not significant.

\subsection{Concentration of ions in tissues}

Leaf B concentration was enhanced significantly at 5 mg kg ${ }^{-1}$ compared to the other B treatments, and this occurred in both soils (Table 2). Also, the plants grown in the acidic soil had slightly higher B concentration in leaves than those in the limed soil, but the difference was significant only at $5 \mathrm{mg} \mathrm{kg}^{-1}$. Boron concentration in roots and rootstock did not exhibit any significant differences between the two $\mathrm{pH}$ treatments when same $\mathrm{B}$ treatments are compared. Root B concentration was significantly elevated at 3 and $5 \mathrm{mg} \mathrm{kg}^{-1}$ compared to the control in the limed soil, while only at $5 \mathrm{mg} \mathrm{kg}^{-1}$ in the acidic soil. In rootstock B concentrations there were significant differences at $5 \mathrm{mg} \mathrm{kg}^{-1}$ compared to the control in both soils. Also, increasing the amount of supplied B, leaf $\mathrm{N}$ concentration decreased $(p=$ 0.001 ), especially for plants grown in the acidic soil, where the decline was statistically significant: in the 5 mg B kg-1 treatment leaf $\mathrm{N}$ declined by $32 \%$ compared to the control. Moreover, leaf $\mathrm{K}$ concentration was positively affected by added B, but this effect was significant in the acidic soil only, where the two higher added B treatments were elevated compared to the control. 
Table 1. Plant growth parameters of apple plants in both the limed and the acidic soils, at the end of the experiment.

\begin{tabular}{|c|c|c|c|c|c|}
\hline $\begin{array}{c}\text { Added B } \\
\text { (mg kg-1 soil) }\end{array}$ & $\begin{array}{l}\text { Internode } \\
\text { length } \\
\text { (cm) }\end{array}$ & $\begin{array}{c}\text { Total } \\
\text { length } \\
\text { of new } \\
\text { shoots } \\
\text { (cm) }\end{array}$ & $\begin{array}{l}\text { Plant } \\
\text { height } \\
(\mathrm{cm})\end{array}$ & $\begin{array}{c}\text { Stem } \\
\text { diameter } \\
(\mathrm{mm})\end{array}$ & $\begin{array}{c}\text { Plant } \\
\text { fresh } \\
\text { matter } \\
\text { weight } \\
\text { (g) }\end{array}$ \\
\hline \multicolumn{6}{|l|}{ Limed } \\
\hline 0 & $0.63 \mathrm{a}$ & $38.4 \mathrm{a}$ & $54 \mathrm{a}$ & $9.89 \mathrm{~b}$ & $95.9 \mathrm{~b}$ \\
\hline 1 & $0.45 \mathrm{ab}$ & $34.5 \mathrm{a}$ & $40 \mathrm{~b}$ & $11.35 \mathrm{~b}$ & $138.2 \mathrm{ab}$ \\
\hline 3 & $0.37 \mathrm{~b}$ & $45.2 \mathrm{a}$ & 60 a & $13.50 \mathrm{ab}$ & $86.0 \mathrm{~b}$ \\
\hline 5 & $0.44 \mathrm{ab}$ & $48.2 \mathrm{a}$ & 77 a & $16.85 \mathrm{ab}$ & $119.4 \mathrm{ab}$ \\
\hline \multicolumn{6}{|l|}{ Acidic } \\
\hline 0 & $0.48 \mathrm{ab}$ & $41.6 \mathrm{a}$ & 63 a & $10.34 \mathrm{~b}$ & $63.5 \mathrm{~b}$ \\
\hline 1 & $0.39 \mathrm{~b}$ & $21.4 \mathrm{a}$ & $70 \mathrm{a}$ & $19.29 \mathrm{ab}$ & $103.7 \mathrm{ab}$ \\
\hline 3 & $0.43 \mathrm{ab}$ & $36.0 \mathrm{a}$ & 64 a & $26.38 \mathrm{a}$ & $178.7 \mathrm{a}$ \\
\hline 5 & $0.55 \mathrm{ab}$ & $35.4 \mathrm{a}$ & $58 \mathrm{a}$ & $15.26 \mathrm{ab}$ & $184.3 \mathrm{a}$ \\
\hline
\end{tabular}

Note: The values in the same column followed by the same letters are not significantly different at the 0.05 probability level, according to Duncan multiple range test.

Table 2. Chemical composition of apple plants in both the limed and the acidic soils, at the end of the experiment.

\begin{tabular}{ccccccccc}
\hline $\begin{array}{c}\text { Added B } \\
\left(\mathbf{m g ~ k g} \mathbf{~}^{-1} \mathbf{~ s o i l ) ~}\right.\end{array}$ & $\mathbf{B}(\mathbf{l})$ & $\mathbf{B}(\mathbf{r})$ & $\mathbf{B}(\mathbf{r s})$ & $\mathbf{N}$ & $\mathbf{K}$ & $\mathbf{F e}$ & $\mathbf{M n}$ & $\mathbf{Z n}$ \\
\hline $\begin{array}{c}\text { Limed } \\
0\end{array}$ & & & & & & & & \\
1 & $41.1 \mathrm{c}$ & $15.9 \mathrm{c}$ & $14.9 \mathrm{c}$ & $15.6 \mathrm{ab}$ & $3.2 \mathrm{bc}$ & $226.1 \mathrm{a}$ & $575 \mathrm{abc}$ & $25.9 \mathrm{bc}$ \\
3 & $37.2 \mathrm{c}$ & $30.0 \mathrm{ab}$ & $23.2 \mathrm{~b}$ & $14.1 \mathrm{bc}$ & $3.9 \mathrm{abc}$ & $101.7 \mathrm{~b}$ & $273 \mathrm{~d}$ & $20.3 \mathrm{bc}$ \\
5 & $55.5 \mathrm{~b}$ & $36.7 \mathrm{a}$ & $31.7 \mathrm{a}$ & $13.4 \mathrm{bc}$ & $3.1 \mathrm{bc}$ & $137.9 \mathrm{~b}$ & $476 \mathrm{c}$ & $19.5 \mathrm{bc}$ \\
\hline Acidic & & & & & & & & \\
0 & $39.6 \mathrm{bc}$ & $17.7 \mathrm{c}$ & $12.9 \mathrm{c}$ & $17.1 \mathrm{a}$ & $2.9 \mathrm{c}$ & $102.4 \mathrm{~b}$ & $554 \mathrm{bc}$ & $22.8 \mathrm{bc}$ \\
1 & $41.2 \mathrm{bc}$ & $18.0 \mathrm{c}$ & $19.4 \mathrm{bc}$ & $15.8 \mathrm{ab}$ & $3.2 \mathrm{bc}$ & $94.3 \mathrm{~b}$ & $585 \mathrm{abc}$ & $33.2 \mathrm{~b}$ \\
3 & $50.3 \mathrm{bc}$ & $25.7 \mathrm{bc}$ & $22.8 \mathrm{~b}$ & $12.7 \mathrm{bc}$ & $4.2 \mathrm{ab}$ & $94.2 \mathrm{~b}$ & $669 \mathrm{ab}$ & $49.0 \mathrm{a}$ \\
5 & $73.2 \mathrm{a}$ & $34.5 \mathrm{ab}$ & $26.6 \mathrm{ab}$ & $10.9 \mathrm{c}$ & $4.8 \mathrm{a}$ & $91.9 \mathrm{~b}$ & $731 \mathrm{a}$ & $17.5 \mathrm{c}$ \\
\hline
\end{tabular}

Note: $\mathrm{B}(\mathrm{l}), \mathrm{B}(\mathrm{r}), \mathrm{B}(\mathrm{rs})$, boron content in leaves, roots and rootstocks ( $\mathrm{mg} \mathrm{kg}^{-1}$ dry matter), respectively; $\mathrm{N}$, $\mathrm{K}$, nitrogen and potassium content in leaves ( $\mathrm{g} \mathrm{kg}^{-1}$ dry matter), respectively; $\mathrm{Fe}, \mathrm{Mn}, \mathrm{Zn}$, iron, manganese, zinc content in leaves $\left(\mathrm{mg} \mathrm{kg}^{-1} \mathrm{dry}\right.$ matter), respectively. The values in the same column followed by the same letters are not significantly different at the 0.05 probability level, according to Duncan multiple range test. 
Leaf $\mathrm{K}$ at $5 \mathrm{mg} \mathrm{kg}^{-1}$ was higher in the acidic soil compared to the same treatments in the limed soil, while no other significant differences were observed between the two $\mathrm{pH}$ treatments, when same B treatments are compared. As regards the micronutrient concentrations in leaves, according to the analysis of variance, soil $\mathrm{pH}$ had a significant impact on leaf $\mathrm{Fe}$ concentration $(p=0.02)$. I.e., the plants grown in the limed soil had a higher Fe concentration than those grown in acidic soil at control. Leaf Fe concentration was negatively affected by $\mathrm{B}$ addition in the limed soil, where it decreased by more than $50 \%$ at $3 \mathrm{mg}$ $\mathrm{kg}^{-1}$ compared to the control, while in the acidic soil there was a non-significant c. 10\% decrease compared to the control. As for $\mathrm{Mn}$, its concentration in leaves was significantly affected by soil $\mathrm{pH}(p<0.001)$ and it was higher in the acidic soil. More specifically, liming significantly decreased leaf Mn levels at 3 and $5 \mathrm{mg}$ $\mathrm{kg}^{-1}$ compared to the same B treatments in the acidic soil. On the other hand, leaf Mn concentration was affected by added $\mathrm{B}$ at $3 \mathrm{mg} \mathrm{kg}^{-1}$ in the limed soil (Mn decreased), while leaf $\mathrm{Mn}$ increased significantly at 5 $\mathrm{mg} \mathrm{kg}^{-1}$ in the acidic soil. Moreover, plants grown in the acidic soil were positively correlated with added $\mathrm{B}\left(\mathrm{r}^{2}=0.97\right.$, significant at $\left.p<0.05\right)$. According to the analysis of variance, soil $\mathrm{pH}$ had a significant impact on $\mathrm{Zn}$ concentration $(p=0.014)$, as the plants grown in the acidic soil had a higher $\mathrm{Zn}$ concentration in leaves at 1 and $3 \mathrm{mg} \mathrm{kg}^{-1}$ compared to the limed soil. Leaf $\mathrm{Zn}$ concentration was decreased with added B in the limed soil, but this was not statistically significant.

Table 3. Chlorophyll concentration of leaves of apple plants in both the limed and the acidic soils, at the end of the experiment.

\begin{tabular}{ccccl}
\hline $\begin{array}{c}\text { Added B } \\
\left(\mathbf{m g ~ k g}^{-1} \text { soil }\right)\end{array}$ & Chl $\boldsymbol{a}$ & \multicolumn{1}{c}{ Chl $\boldsymbol{b}$} & Chl $\mathbf{a}+\boldsymbol{b}$ & \multicolumn{1}{c}{ Chl $\mathbf{b} / \mathbf{a}$} \\
\hline Limed & & & \\
\hline 0 & $5.13 \mathrm{~b}$ & $1.53 \mathrm{~d}$ & $6.60 \mathrm{~b}$ & $0.31 \mathrm{c}$ \\
1 & $4.70 \mathrm{~b}$ & $1.73 \mathrm{~cd}$ & $6.43 \mathrm{~b}$ & $0.38 \mathrm{bc}$ \\
3 & $5.57 \mathrm{~b}$ & $2.62 \mathrm{bcd}$ & $8.20 \mathrm{~b}$ & $0.45 \mathrm{abc}$ \\
5 & $7.31 \mathrm{ab}$ & $3.99 \mathrm{abc}$ & $11.30 \mathrm{ab}$ & $0.54 \mathrm{ab}$ \\
\hline Acidic & & & & \\
0 & $9.35 \mathrm{a}$ & $5.73 \mathrm{a}$ & $15.08 \mathrm{a}$ & $0.62 \mathrm{a}$ \\
1 & $4.57 \mathrm{~b}$ & $2.75 \mathrm{bcd}$ & $7.32 \mathrm{~b}$ & $0.61 \mathrm{a}$ \\
3 & $9.22 \mathrm{a}$ & $4.52 \mathrm{ab}$ & $13.74 \mathrm{a}$ & $0.41 \mathrm{abc}$ \\
5 & $4.47 \mathrm{~b}$ & $2.08 \mathrm{~cd}$ & $6.55 \mathrm{~b}$ & $0.46 \mathrm{abc}$ \\
\hline
\end{tabular}

Note: Chl $a$, Chl $b, \mathrm{Chl} a+b$, foliar mass-based chlorophyll $a$, chlorophyll $b$ and total chlorophyll content (mg g ${ }^{-1}$ dry matter), respectively; Chl $b / a$, the ratio of chlorophyll $b$ and $a$ mass-based content. The values in the same column followed by the same letters are not significantly different at the 0.05 probability level, according to Duncan multiple range test. 


\subsection{Leaf chlorophyll}

The addition of B led to a decrease in total Chl (Chl $a+b)$ concentration in the acidic soil at 1 and $5 \mathrm{mg}$ $\mathrm{kg}^{-1}$, while no effect was observed in the limed soil (Table 3). Also, in the non-fertilized (control) plants in the acidic soil, total $\mathrm{Chl}$ concentration was higher by $128 \%$ than those in the limed soil. Chl $a$, as well as $\mathrm{Chl} b$, concentrations in leaves were significantly reduced in the plants treated with 1 and $5 \mathrm{mg} \mathrm{B} \mathrm{kg}^{-1}$, but only in the acidic soil. Contrary to that, in the limed soil, a significant increase compared to the control was recorded at $5 \mathrm{mg} \mathrm{kg}^{-1}$ for $\mathrm{Chl} b$. Chl $b$ was also significantly affected $(p=0.043)$ by soil $\mathrm{pH}$, as it increased in the acidic soil at control.

Chl $b / a$ ratio increased with added $\mathrm{B}$ in the limed soil, and at $5 \mathrm{mg} \mathrm{kg}^{-1}$ the difference was significant compared to the control, while it was not affected by added $B$ in the acidic soil. Also, the analysis of variance indicated that $\mathrm{Chl} b / a$ was significantly affected by soil $\mathrm{pH}(p=0.036)$, as it was higher in the acidic soil than in the limed at control and at $1 \mathrm{mg} \mathrm{kg}^{-1}$.

\section{Discussion}

None of the studied apple agronomic parameters were adversely affected by added B, not even in the acidic soil, where $\mathrm{B}$ availability was expected to be relatively high. There were even parameters that exhibited some increase with added B, although, as recorded earlier, according to the strict criteria of the statistical interpretation employed here, there were only but a few significant increases compared to the unamended control. However, increasing the amount of added B in acidic soil led to an increase of fresh matter weight of plants. In the limed soil there were not significant effects and this may be attributed to lower B availability in that soil. Similar results have been reported elsewhere for apples (Wojcik, 2006a) as well as for other crops (Yunsheng et al., 2003; Rajeswara and Rajput, 2011). Contrary to our findings, there are reports suggesting a decrease of plant weight under B excess conditions (Sotiropoulos et al., 2002; Soylemezoglu et al., 2009). However, the doses of $\mathrm{B}$ used in the experiments reported in those works were much higher than ours. In line with added B, no agronomic parameter seemed to have been affected by the other studied variable, i.e., soil $\mathrm{pH}$, except for fresh weight and stem diameter, which responded to some degree to liming (fresh weight decreased with liming at the high $\mathrm{B}$ additions, but the effect was significant only at $3 \mathrm{mg} \mathrm{kg}^{-1)}$. Similarly results have been reported by Wooldridge (2002a). The positive effect of B on stem diameter may be related to the important role that it has in cell wall synthesis.

During our experiment, leaf B concentration in both soils had a positive correlation with the amount of added $\mathrm{B}$. The correlation in the limed soil $\left(\mathrm{r}^{2}=0.84\right.$, significant at $p<0.05$ ) was stronger than that in the acidic $\left(\mathrm{r}^{2}=0.67\right.$, also significant at $\left.p<0.05\right)$. Other studies where B fertilization increased apple leaf B concentration include that of Wojcik et al. (2008), Wooldridge (2002b) and Peryea et al. (2003), who used B sprays in the prebloom period in the midseason leaves. Also, in line with our findings, close correlation of B content in soil and leaves was found for apple and cherry (Wojcik, 2006a; 2006b). Our results also indicate the great importance of soil $\mathrm{pH}$ on B uptake. All B treatments in the acidic soil had higher leaf B concentrations than those in the limed soil, and the difference was further enhanced with added B (it actually became significant at $5 \mathrm{mg} \mathrm{kg}^{-1}$ ). Similar results were reported in experiments with cotton that involved soil liming (Tsadilas et al., 2005). Regarding $\mathrm{B}$ in roots, its correlation with the applied amount of $\mathrm{B}$ was linear in both limed and acidic soils ( $\mathrm{r}^{2}$ equal to 0.96 and 0.90 , respectively). In line with this, similar effects of $\mathrm{B}$ addition on $\mathrm{B}$ accumulation in roots were reported for olive (Chatzissavvidis and Therios, 2010), grapevine (Yermiyahu et al., 2006) and citrus (Papadakis et al., 2004). Rootstock B concentration exhibited similar positive responses to added B, as those found for leaves and roots. Correlation analyses conducted for both soils confirmed this trend $\left(\mathrm{r}^{2}=\right.$ 
0.97 , same value for both soils, significant at $p<0.05$ ). Rootstock plays an important role in B transpiration, as B is transported through xylem to upper organs. Wojcik et al. (2003) also confirmed the importance of rootstock in apple cultivation and the response of rootstock B to added B (although they dealt with a low B availability situation). It is well known that the apoplast harbours $50-98 \%$ of plant B by forming esters containing $\mathrm{B}$, and that these reactions are $\mathrm{pH}$ dependent (Wimmer and Goldbach, 2007). In the present experiment the effect of soil $\mathrm{pH}$ on leaf $\mathrm{B}$ was clear only at $5 \mathrm{mg} \mathrm{kg}^{-1}$, and this seems to suggest that the excessive $\mathrm{B}$ was translocated via the respiration flow to leaves.

The levels of $\mathrm{N}$ concentration in leaves decreased as the amount of applied B increased. Therefore, the control plants in both soil types had higher $\mathrm{N}$ concentration than the plants fertilized with $\mathrm{B}$. Soil $\mathrm{pH}$ did not seem to have affected $\mathrm{N}$ availability, but the latter was affected by added (and, consequently, available) B. Our results suggest an antagonism between $\mathrm{B}$ and $\mathrm{N}$, which is likely to have occurred due to the preferred B uptake in the expense of N. Since N availability is not typically affected by soil $\mathrm{pH}$, increased $\mathrm{B}$ levels relative to $\mathrm{N}$ (which was not added) seemed to be the decisive factor for the preferential uptake of $\mathrm{B}$ over N. Interestingly, similar results were also reported by Dursun et al. (2010) and Esringu et al. (2011), in experiments reporting results on vegetable crops.

Potassium levels showed an increase in both soils (although this effect was significant at 3 and $5 \mathrm{mg}$ $\mathrm{kg}^{-1}$ in the acidic soil only). This increase with added B seems to disprove the expected B-K antagonism, as suggested e.g. by Chatzissavvidis et al. (2007), who reported that increasing $\mathrm{B}$ levels in the nutrient solution, led to a decline in $\mathrm{K}$ concentration of olive (Olea europaea L.) leaves. However, we do not confirm this antagonism here because the situation was vastly different in our study: Potassium was not abundant in soil. In fact in an acidic soil, $\mathrm{K}$ is expected to be rather low, if not nearly depleted. Added B seemed to improve apple root ability to absorb important macronutrients, which in the case of the low-status $\mathrm{K}$, contrary to the relatively abundant $\mathrm{N}$, led to the enhancement of its uptake. Indeed, control plant levels are as suggested: Relatively high $\mathrm{N}$ (nearly $2 \mathrm{~g} \mathrm{~kg}^{-1}$ in the acidic soil) and relatively low $\mathrm{K}$ (less than $0.3 \mathrm{~g}$ $\mathrm{kg}^{-1}$ in the acidic soil). Other works have also reported enhanced K uptake with added B (e.g., Dursun et al., 2010; Chatzissavvidis and Therios, 2010).

Iron decreased in both soils with added B (although the effect was only significant in the limed soil). In the limed soil, Fe concentration decreased a lot more dramatically, by nearly a factor of 2 , than in the acidic soil. Our data indicate that the observed antagonism of B towards Fe (i.e., preferred uptake of added B over the well-supplied $\mathrm{Fe}$, a trace metal typically with high availability in acidic soils) was more severe in the limed soil, where Fe availability was expected to be lower (Grewal, 2010). Similar results were found for potted olive plantlets (Chatzissavvidis and Therios, 2010).

As for Mn, it seemed to be unaffected by added B (small variations within soils were not significant), but was greatly (and significantly) affected by liming. The explanation seems to be connected with the unusually high Mn levels in leaves (probably induced by a field application of a Mn-containing soil/plant protective additive prior to our soil sampling). Liming decreased Mn availability and this served as a physiological factor for impeding excess Mn uptake. To this, added B did not seem to have any particular role.

Zinc in the limed soil was not affected by added B (there was a slight, non-significant, decreasing trend), but in the acidic soil there was a positive effect (the increase in $\mathrm{Zn}$ was significant at $3 \mathrm{mg} \mathrm{kg}^{-1}$ ). We suggest that in the limed soil, where soil conditions are relatively unfavourable for $\mathrm{Zn}$ availability, added B suppressed $\mathrm{Zn}$ uptake, and thus served as a physiological function to lower $\mathrm{Zn}$ levels. In the acidic soil, however, where trace metal availability cannot be easily suppressed, $\mathrm{B}$ additions, having improved agronomic and thus growth conditions, led to the "side-effect" of a further enhancement of $\mathrm{Fe}$ uptake. Various works report 
similar trends (Sotiropoulos et al., 2002; Esringu et al., 2011).

Chlorophyll (especially total $\mathrm{Chl}$ and $\mathrm{Chl} b$ ) tended to decrease with added B. Stavrianakou et al. (2006) provided a likely explanation for a link between B and $\mathrm{Chl}$ content, suggesting that low B levels may be responsible for the development of thicker cell walls, thus for higher Chl content. In this study, although B levels were not low, our data indicate that this suggested link is still a possible explanation through extrapolation: Increased B levels may be causing thinner cell walls, and thus lower Chl content. The increased $\mathrm{Chl} b / a$ ratio caused by the added $\mathrm{B}$ may be attributed to the decreased thickness of cell walls and, consequently, to enhanced penetration of a wider spectrum of light. It should also be noted that the trends of Chl with added $\mathrm{B}$ are very similar to those of leaf $\mathrm{N}$. The connection between the two ( $\mathrm{N}$ and $\mathrm{Chl})$ is well established, thus the decreased $\mathrm{Chl}$ contents may also have been triggered by the reduced $\mathrm{N}$ concentrations with added B.

Finally, soil $\mathrm{pH}$ also seemed to have an important role in the concentration of $\mathrm{Chl}$, as it decreased with liming in the control soil. Boron availability is dependent on soil $\mathrm{pH}$ and $\mathrm{Chl}$ concentration on $\mathrm{B}$, thus there was the observed link between $\mathrm{pH}$ and $\mathrm{Chl}$. Other researchers, who studied apple plantlets and mandarin plants treated with $\mathrm{B}$, also reported the same decreasing trend with added B (Mouhtaridou et al., 2004; Papadakis et al., 2004).

\section{Conclusions}

Our results suggest that B can play a key role in the fertilization program of apple. We conclude that in high B-content acidic soils neither liming nor addition of extra B seemed to have any negative effects on any of the studied apple plant agronomic characteristics, nor did they create significant nutrient imbalances, at least in cases of $\mathrm{B}$ being added to soil up to a level of 1-3 $\mathrm{mg} \mathrm{B} \mathrm{kg}^{-1}$.

\section{Acknowledgements}

The authors wish to express their gratitude to the postgraduate student Mr. Konstantinos Samaras for his contribution to $\mathrm{K}$ determination in apple leaves.

\section{References}

Bingham, F.T. 1982. Boron. In: A.L. Page, R.H. Miller, D.R. Keeney (eds.). Methods of Soil Analysis. Part 2. Chemical and Microbiological Properties. American Society of Agronomy, Madison, WI, pp: 431-448.

Chatzissavvidis, C., Therios, I. 2010. Response of four olive (Olea europaea L.) cultivars to six B concentrations: Growth performance, nutrient status and gas exchange parameters. Sci. Hortic. 127, 29-38.

Chatzissavvidis, C.A., Therios, I.N., Antonopoulou, C. 2007. Effect of nitrogen source in olives growing in soils with high boron content. Aust. J. Exp. Agric. 47, 1491-1497.

Dursun, A., Turan, M., Mkinci, M., Gunes, A., Ataoglu, N., Esringü, S., Yildirim, E. 2010. Effects of boron fertilizer on tomato, pepper, and cucumber yields and chemical composition. Comm. Soil Sci. Plant Anal. 41, 1576-1593.

Esringu, A., Turan, M., Gunes, A., Esitken, E., Sambo, S. 2011. Boron application improves on yield and chemical composition of strawberry. Acta Agric. Scand. Section B-Soil and Plant Sci. 61, 245-252.

Goldbach, H., Wimmer, M. 2007. Boron in plants and animals: Is there a role beyond cell-wall structure? J. Plant Nutr. Soil Sci. 170, 39-48.

Goldberg, S. 1995. Chemistry and Mineralogy of Boron in Soils. In: U.C. Gupta (ed.). Boron and its Role in Crop Production. CRC Press, Boca Raton, Florida, USA, pp: 10-11. 
Grewal, H. 2010. Alfalfa responses to combined use of lime and limiting nutrients on an acidic soil. Comm. Soil Sci. Plant Anal. 41, 2247-2263.

Jones, J.B.Jr. 1991a. Kjeldahl Method for Nitrogen Determination. Micro-Macro Publishing, Athens, Georgia, USA, pp: 3-20.

Jones, J.B.Jr. 1991b. Plant Tissue Analysis in Micronutrients. In: J.J. Mortvedt, F.R. Cox, L.M. Shuman, R.M. Welch (eds.). Micronutrients in Agriculture. 2nd edition. Number 4 book series. Soil Science Society of America, WI, USA, pp: 477-521.

Jones, J.B.Jr. 1998. Plant Nutrition Manual. CRC Press, Boca Raton, Florida, pp: 60-61.

Mezuman, U., Keren, R. 1981. Boron absorption by soils using a phenomenological absorption equation. Soil Sci. Soc. Am. J. 45, 722-726.

Mouhtaridou, G., Sotiropoulos, T., Dimassi, K., Therios, I. 2004. Effects of boron on growth, and chlorophyll and mineral contents of shoots of the apple rootstock MM 106 cultured in vitro. Biol. Plant. 48, 617-619.

Papadakis, I., Dimassi, K., Bosabalidis, A., Therios, I., Patakas, A., Giannakoula, A. 2004. Boron toxicity in 'Clementine' mandarin plants grafted on two rootstocks. Plant Sci. 166, 539-547.

Peryea, J., Neilsen, D., Neilsen, G. 2003. Boron maintenance sprays for apple: Early-season applications and tank-mixing with calcium chloride. HortScience. 38, 542-546.

Rajeswara, R., Rajput, D. 2011. Response of palmarosa \{Cymbopogon martinii (Roxb.) Wats. var. motia Burk.\} to foliar application of magnesium and micronutrients. Industr. Crops Prod. 33, 277-281.

Reid, R., Hayes, J., Post, A., Stangoulis, J., Graham, D. 2004. A critical analysis of the causes of boron toxicity in plants. Plant Cell Env. 25, 1405-1414.
Shuang, H., Ning, T., Huan-Xin, J., Lin-Tong, Y., Yan, L., Li-Song, C. 2009. $\mathrm{CO}_{2}$ assimilation, photosystem II photochemistry, carbohydrate metabolism and antioxidant system of citrus leaves in response to boron stress. Plant Sci. 176, 143-153.

Sotiropoulos, T., Therios, I., Dimassi, K., Bosabalidis, A., Kofidis, G. 2002. Nutritional status, growth, $\mathrm{CO}_{2}$ assimilation, and leaf anatomical responses in two kiwifruit species under boron toxicity. J. Plant Nutr. 25, 1249-1261.

Soylemezoglu, G., Demir, K., Inal, A., Gunes, A. 2009. Effect of silicon on antioxidant and stomatal response of two grapevine (Vitis vinifera L.) rootstocks grown in boron toxic, saline and boron toxic-saline soil. Sci. Hortic. 123, 240-246.

Stavrianakou, S., Liakopoulos, G., Karabourniotis, G. 2006. Boron deficiency effects on growth, photosynthesis and relative concentrations of phenolics of Dittrichia viscosa (Asteraceae). Env. Exp. Bot. 56, 293-300.

Tsadilas, C., Kassioti, T., Mitsios, I. 2005. Influence of liming and nitrogen forms on boron uptake by tobacco. Comm. Soil Sci. Plant Anal. 36, 701-708.

Wimmer, M.A., Goldbach, H.E. 2007. Boron in the apoplast of higher plants. In: B. Sattelmacher, W.J. Horst (eds). The Apoplast of Higher Plants: Compartment of Storage, Transport, and Reactions. The Significance of the Apoplast for the Mineral Nutrition of Higher Plants. Springer, Dordrecht, The Netherlands, pp: 19-32.

Wintermans, J.F.G.M., De Mots, A. 1965. Spectrophotometric characteristics of chlorophylls $\mathrm{a}$ and $\mathrm{b}$ and their phenophytins in ethanol. Bioch. Bioph. Acta. 109, 448-453.

Wojcik, P. 2006a. Effect of postharvest sprays of boron and urea on yield and fruit quality of apple trees. J. Plant Nutr. 29, 441-450. 
Wojcik, P. 2006b. 'Schattenmorelle' tart cherry response to boron fertilization. J. Plant Nutr. 29, 1709-1718.

Wojcik, P., Wojcik, M., Klamkowski, K. 2008. Response of apple trees to boron fertilization under conditions of low soil boron availability. Sci. Hortic. $116,58-64$.

Wojcik, P., Wojcik, M., Treder, W. 2003. Boron absorption and translocation in apple rootstocks under conditions of low medium boron. J. Plant Nutr. 26, 961-968.
Wooldridge, J. 2002b. Effect of foliar- and soil-applied boron in deciduous fruit orchards: Apple and pear. S. Afr. J. Plant Soil. 19, 137-144.

Yermiyahu, U., Ben-Gal, U., Sarig, P. 2006. Boron toxicity in grapevine. HortScience 41, 1698-1703.

Yunsheng, L., Yongchao, L., Yuai, Y., Bell, R. 2003. Effect of fertilization on plant growth and nutrient uptake in oilseed rape under varying boron supply. Comm. Soil Sci. Plant Anal. 34, 1059-1075. 